\title{
PERBANDINGAN PENERAPAN SAK-ETAP DAN PSAK 50 DAN 55 ATAS PENURUNAN NILAI (IMPAIRMENT) PIUTANG PADA PT. BPR MILLENIA
}

\author{
Daniela Ribka Frida Mandang ${ }^{1}$ \\ Agus Poputra ${ }^{2}$ \\ Meily Kalalo ${ }^{3}$ \\ ${ }^{1,2,3}$ Fakultas Ekonomi dan Bisnis, Jurusan Akuntansi \\ Universitas Sam Ratulangi Manado. \\ Email : 1 danielamandang@gmail.com
}

\begin{abstract}
One of the bank's biggest revenue is comes from credit. However in distributing credit to society, there is usually an obstacles of the payment of credit to the bank. The bigger the load of bank to make a reserve fund, bank loss itself will reduce the capital. The goal of this research is to understand the differences of the application of SAK and PSAK 50 and 55 on the declining of the receivable. The object of this thesis research is Bank Perkreditan Rakyat Millenia. The method that is used in this research is descriptive method. The result of this research shows that the company used the impairment of receivable align with SAK ETAP and there are differences between SAK ETAP and PSAK 50 and 55 on impairment of receivable.
\end{abstract}

Keywords : Impairment of Receivable, SAK ETAP, PSAK 50 and 55

\section{Latar Belakang}

\section{PENDAHULUAN}

Kegiatan perekonomian suatu negara tidak terlepas dari aliran uang, dimana industri perbankan memegang peranan yang sangat penting dan strategis dalam sistem perekonomian. Menurut Undang-undang Nomor 10 Tahun 1998 tentang Perbankan menyebutkan bahwa fungsi utama perbankan indonesia adalah sebagai penghimpun dan penyalur dana masyarakat yang bertujuan menunjang pelaksanaan pembangunan nasional ke arah peningkatan kesejahteraan rakyat banyak.

Pendapatan terbesar bank berasal dari bunga, imbalan atau pembagian hasil usaha atas kredit yang disalurkan. Semakin banyak jumlah kredit yang disalurkan berarti potensi pendapatan semakin besar. Akan tetapi, dalam pelaksanaannya tidak semua dana yang dihimpun dari masyarakat bisa disalurkan dengan baik sesuai dengan tolak ukur yang telah ditetapkan dan penyaluran kredit kepada masyarakat biasanya mengalami hambatan dalam hal pengembalian pinjaman kepada pihak bank dan nyaris semua bank yang beroperasi di Indonesia mengalami kredit bermasalah. Semakin besar kredit macet yang dihadapi, maka makin menurun pula tingkat kesehatan bank tersebut atau menurunnya profitabilitas yang diharapkan. Semakin besar jumlah kredit bermasalah, makin besar pula jumlah cadangan yang harus disediakan serta makin besar pula tanggungan bank untuk mengadakan dana cadangan tersebut karena kerugian bank akan mengurangi modal sendiri.

Bank Perkreditan Rakyat (BPR) merupakan salah satu pendukung perkembangan perekonomian indonesia, terutama untuk kegiatan usaha mikro, kecil, dan menengah serta sektor informal. Peran BPR dalam pemberian kredit bagi usaha mikro, kecil, dan menengah ini dapat membantu menciptakan lapangan pekerjaan, pemerataan pendapatan, dan pemerataan kesempatan berusaha di Indonesia.

Salah satu ruang lingkup kegiatan Bank Perkreditan Rakyat Millenia adalah memberikan fasilitas kredit kepada sektor usaha, dimana kredit tersebut bersumber dari dana yang dihimpun dari giro, deposito, dan tabungan. Dalam menjalankan fungsinya sebagai BPR, kebijaksanaan perkreditan Bank Perkreditan Rakyat Millenia senantiasa diarahkan pada semua sektor usaha dengan pemberian kredit jangka pendek dan menengah serta prioritas sektor-sektor yang dapat mendorong pertumbuhan ekonomi.

Saat ini standar akuntansi keuangan sedang dalam proses konvergensi dengan IFRS, sehingga penyusunan laporan keuangan menjadi lebih kompleks dan banyak menggunakan fair value, 
professional judgment. Kondisi demikian cukup menyulitkan bagi sebagian besar perusahaan di Indonesia, terutama bagi perusahaan mikro, kecil, dan menengah. Oleh karena itu, Ikatan Akuntan Indonesia mengeluarkan Standar Akuntansi Keuangan untuk Entitas Tanpa Akuntabilitas Publik (SAK ETAP). SAK ETAP diperuntukkan bagi entitas yang tidak mempunyai akuntabilitas publik yang signifikan. Namun, regulator dapat menetapkan entitas yang mempunyai akuntabilitas publik yang signifikan untuk menggunakan SAK ETAP.

Sistem akuntansi baru ini memperkenalkan "impairment" atau penurunan atas nilai piutang. Penurunan nilai yaitu suatu kondisi dimana terdapat bukti obyektif terjadinya peristiwa yang merugikan sebagai akibat dari satu atau lebih peristiwa yang terjadi setelah pengakuan awal kredit. Penurunan nilai piutang data dihitung dengan dua cara yaitu secara individu dan dihitung secara kolektif.

Berdasarkan latar belakang yang telah diuraikan diatas maka penulis merumuskan masalah yang akan diteliti dalam penulisan skripsi ini adalah "Bagaimana perbedaan penerapan penurunan nilai berdasarkan SAK-ETAP dan PSAK 50 dan 55 pada PT. BPR Millenia?”

\section{Tujuan Penelitian}

Tujuan penelitian ini adalah untuk memahami perbedaan penerapan SAK-ETAP dan PSAK 50 dan 55 atas penurunan nilai (impairment) piutang pada PT. BPR Millenia Manado.

\section{Manfaat Penelitian}

Manfaat yang diharapkan dari penelitian ini adalah sebagai berikut.

1. Penelitian ini bermanfaat bagi penulis sebagai tambahan pengalaman dan pengetahuan tentang bagaimana perbandingan penerapan SAK-ETAP dan PSAK 50 dan PSAK 55 atas penurunan nilai piutang pada PT BPR Millenia Manado.

2. Penelitian ini diharapkan dapat memberikan masukan kepada perusahaan mengenai peneurunan nilai piutang (kredit yang diberikan) berdasarkan SAK-ETAP dan memberi pengetahuan tambahan berupa penerapan PSAK 50 dan PSAK 55 yang dapat dimanfaatkan sebagai alat bantu untuk mendapatkan dan mengetahui pengukuran, pengakuan, serta penyajian penurunan nilai piutang dalam laporan keuangan yang sesuai dengan ketentuan dan standar akuntansi yang tepat dan berguna jika perusahaan ingin menjadi go public dan menjadi perusahaan yang lebih besar dalam hal ini menjadi bank umum.

\section{Kredit}

\section{TINJAUAN PUSTAKA}

Menurut Undang-undang Nomor 10 Tahun 1998 mengenai Pokok-Pokok Perbankan, pengertian kredit adalah penyediaan uang atau tagihan yang dapat dipersamakan dengan itu, berdasarkan persetujuan atau kesepakatan pinjam meminjam antara bank dengan pihak lain yang mewajibkan pihak peminjam melunasi utangnya setelah jangka waktu tertentu dengan pemberian bunga.

A line of credit is a commitment in which a borrower receives a promise from a bank to provide a loan over a set period at predetermined terms. Theory suggests that credit lines provide the borrower insurance against future liquidity shocks and thus play a key liquidity role. (Demiroglu \& James, 2010)

Menurut Taswan (2008 : 215) Pengertian kredit adalah : "Penyediaan uang atau tagihan yang dapat dipersamakan dengan itu berdasarkan persetujuan atau kesepakatan pinjam-meminjam antar bank dengan pihak lain yang mewajibkan pihak peminjam untuk melunasi utangnya setelah jangka waktu tertentu dengan pemberian bunga, imbalan atau pembagian hasil keuntungan".

\section{Kredit Bermasalah}

Kredit bermasalah adalah suatu keadaan dimana nasabah sudah tidak sanggup membayar sebagian atau seluruh kewajibannya kepada bank seperti yang telah diperjanjikannya. Kredit bermasalah menurut ketentuan Bank Indonesia merupakan kredit yang digolongkan ke dalam kolektibilitas Kurang Lancar (KL), Diragukan (D), dan Macet (M). (Fitria \& Sari, 2012)

Kredit bermasalah yaitu kredit yang dalam pelaksanaannya belum mencapai/memenuhi target yang diinginkan oleh pihak bank kemudian memiliki kemungkinan timbulnya risiko kemudian hari bagi bank dalam arti luas, juga mengalami kesulitan dalam penyelesaian kewajiban-kewajiban baik dalam bentuk pembayaran kembali pokoknya dan atau pembayaran bunga, denda keterlambatan serta 
ongkos-ongkos bank yang menjadi beban debitur yang bersangkutan. Kredit bermasalah adalah suatu keadaan dimana nasabah sudah tidak sanggup membayar sebagian atau seluruh kewajibannya kepada bank seperti yang telah diperjanjikan. (Kuncoro dan Suharjono, 2002).

\begin{abstract}
Akuntansi
Menurut Ismail (2014:2), akuntansi dapat diartikan sebagai seni dalam melakukan pencatatan, penggolongan, dan pengikhtisaran, yang mana hasil akhirnya tercipta sebuah informasi seluruh aktivitas keuangan perusahaan. Tujuan akuntansi yang digambarkan dalam laporan keuangan adalah untuk memberikan informasi yang bermanfaat untuk pengambilan keputusan para pemakai.

Menurut Committee on Terminology of The American Institute of Certified Public Accountants yang dikutip oleh Belkaoui (2011 : 50), akuntansi adalah seni mencatat, menggolongan, dan mengikhtisarikan transaksi serta peristiwa yang bersifat keuangan dengan suatu cara yang bermakna dan dalam satuan uang serta menginpretasikan hasil-hasilnya.
\end{abstract}

\title{
Perbankan
}

Menurut (UU) RI Nomor 10 Tahun 1998 dalam buku Kasmir (2012 : 24), bank adalah badan usaha yang menghimpun dana dari masyarakat dalam bentuk simpanan dan menyalurkannya kepada masyarakat dalam bentuk kredit dan atau bentuk-bentuk lainnya dalam rangka meningkatkan taraf hidup rakyat banyak.

Menurut (UU) RI Nomor 10 Tahun 1998 dikutip oleh Kasmir (2012 : 33), Bank Perkreditan Rakyat adalah bank yang melaksanakan kegiatan usaha secara konvensional atau berdasarkan prinsip syariah yang dalam kegiatannya tidak memberikan jasa dalam lalu lintas pembayaran. Artinya disini kegiatan BPR jauh lebih sempit jika dibandingkan dengan kegiatan bank umum.

\section{SAK-ETAP}

Standar Akuntansi Keuangan Entitas Tanpa Akuntabilitas Publik atau SAK-ETAP merupakan standar akuntansi keuangan yang diperuntukkan bagi entitas tanpa akuntabilitas publik. ETAP adalah entitas yang tidak memiliki akuntabilitas publik signifikan dan menerbitkan laporan keuangan untuk tujuan umum (general purpose financial statement) bagi pengguna eksternal. Contoh pengguna eksternal adalah pemilik yang tidak terlibat langsung dalam pengelolaan usaha, kreditur, dan lembaga pemeringkat kredit. (Sumendap, 2015)

Penurunan Nilai terjadi ketika nilai tercatat aset melebihi jumlah yang dapat diperoleh kembali. Entitas harus menilai pada setiap tanggal pelaporan apakah terdapat indikasi bahwa ada aset yang turun nilainya. Penurunan nilai pinjaman dan Piutang yang diberikan dibentuk sebesar estimasi kerugian yang tidak dapat ditagih.

\section{PSAK 50 dan PSAK 55}

\section{PSAK 50 Tentang Instrumen Keuangan : Penyajian}

PSAK 50 merupakan adopsi dari IAS 32 Financial Instrument: presentation. Dalam Paragraf 02 dinyatakan tujuan pernyataan ini adalah menetapkan prinsip penyajian instrumen keuangan sebagai liabilitas atau ekuitas dan saling hapus aset keuangan dan liabilitas keuangan. Pernyataan ini diterapkan untuk klasifikasi instrumen keuangan, dari perspektif penerbit, dalam aset keuangan, liabilitas keuangan, dan instrumen ekuitas; klasifikasi bunga, dividen, kerugian dan keuntungan yang terkait; dan keadaan dimana aset keuangan dan liablitas keuangan saling hapus. Pernyataan ini melengkapi prinsip pengakuan dan pengukuran aset keuangan dan liabilitas keuangan dalam PSAK 55: Instrumen Keuangan: Pengakuan dan Pengukuran.

\section{PSAK No. 55 Tentang Instrumen Keuangan : Pengakuan dan Pengukuran}

Dalam paragraf 01 dinyatakan tujuan pernyataan ini adalah untuk mengatur prinsip dasar pengakuan dan pengukuran aset keuangan, liabilitas keuangan, dan kontrak pembelian atau penjualan item non keuangan. PSAK ini menjelaskan di antaranya definisi derivatif, kategori instrumen keuangan, pengakuan dan pengukuran, akuntansi lindung nilai dan penentuan kriteria lindung nilai.

Pengakuan awal dalam paragraf 14 entitas mengakui aset keuangan atau liabilitas keuangan dalam laporan posisi keuangan, jika dan hanya jika, entitas tersebut menjadi salah satu pihak dalam ketentuan pada kontrak instrumen tersebut. PSAK 55 (revisi 2015) paragraf 43. "Pada saat pengakuan 
awal aset keuangan dan liabilitas keuangan, entitas mengukur pada nilai wajarnya. Dalam hal aset keuangan dan liabilitas keuangan tidak diukur pada nilai wajar melalui laba rugi, nilai wajar tersebut ditambah biaya transaksi yang dapat diatribusikan secara langsung dengan perolehan atau penerbitan aset keuangan dan liabilitas keuangan tersebut. Keempat kategori diterapkan pada pengukuran dan pengakuan laba rugi”.

PSAK 55 (revisi 2015) paragraf 58. “ Pada setiap akhir periode pelaporan, entitas mengevaluasi apakah terdapat bukti efektif bahwa aset keuangan atau kelompok aset keuangan mengalami penurunan nilai". Penurunan nilai adalah suatu kondisi dimana nilai tercatat aset melebihi nilai yang dapat diperoleh kembali.

Aset keuangan atau kelompok aset keuangan diturunkan nilainya dan kerugian penurunan nilai telah terjadi, jika dan hanya jika, terdapat bukti objektif mengenai penurunan nilai sebagai akibat dari satu atau lebih peristiwa yang terjadi setelah pengakuan awal aset tersebut (peristiwa merugikan), dan peristiwa yang merugikan tersebut berdampak pada estimasi arus kas masa depan dari aset keuangan atau kelompok aset keuangan yang dapat diestimasi secara andal. Sulit untuk mengidentifikasi satu peristiwa tertentu yang menyebabkan penurunan nilai.

Penurunan nilai pada dasarnya disebabkan oleh kombinasi dari beberapa peristiwa masa depan tidak dapat diakui, terlepas hal tersebut sangat mungkin terjadi. Bukti objektif bahwa aset keuangan atau kelompok aset keuangan mengalami penurunan nilai termasuk data yang dapat diobservasi yang menjadi perhatian dari pemegang aset tersebut.

\section{Penelitian Terdahulu}

1. Inggrid (2012) mengenai Analisis Pengakuan, Pengukuran, Penyajian, Pengungkapan atas Pendapatan Bunga Kredit Pada PT. Bank Sinarmas Tbk. Penelitian ini, data yang digunakan bersifat kuantitatif. Sumber data dalam penelitian ini adalah data primer, yaitu data yang diperoleh langsung dari objek penelitian. Analisis dilakukan dengan metode deskriptif. Bila dibandingkan penelitian penulis, terdapat beberapa persamaan dan perbedaan. Persamaannya terletak pada jenis dan teknik pengumpulan data serta analisis data yaitu analisis deskriptif. Perbedaannya, penelitian ini dilakukan di perusahaan berbeda dalam penelitian ini.

2. Emanuela (2012) mengenai Analisis Penerapan PSAK 50 dan 55 (revisi 2006) atas Impairment Piutang Pada Perusahaan Multifinance. Penelitian ini menggunakan data yang bersifat kuantitatif yaitu berupa angka-angka yang tercantum dalam laporan keuangan. Sumber data dalam penelitian ini adalah data primer yaitu, data yang diperoleh langsung dari objek penelitian. Analisis di lakukan dengan metode deskriptif komperatif. Bila di bandingkan dengan penelitian penulis, terdapat beberapa persamaan dan perbedaan. Persamaannya adalah melakukan penelitian tentang perlakuan akuntansi Impairment piutang. Perbedaannya, penelitian ini dilakukan di beberapa perusahaan multifinance sedangkan peneliti pada perbankan dan membandingkan antara SAK ETAP dan PSAK.

\section{Jenis Penelitian}

\section{METODE PENELITIAN}

Jenis penelitian ini adalah penelitian Deskriptif. Penelitian ini menekankan pada deskripsi data yang bertujuan untuk memberikan atau menjabarkan sesuatu (Sugiyono, 2011)

\section{Tempat dan Waktu Penelitian}

Penelitian ini dilakukan di Kantor Pusat Bank Perkreditan Rakyat Millenia Jl. Bethesda No. 42 Manado - Sulawesi Utara. Penelitian di lakukan pada bulan Agustus - September 2015.

\section{Metode Pengumpulan Data}

1. Metode pengumpulan kepustakaan (library research)

Pengumpulan data ini dilakukan untuk memperoleh data sekunder yang digunakan sebagai landasan teori yang berkaitan dengan masalah yang diteliti. Untuk data yang sifatnya kuantitatif, pengumpulan datanya pertahun (akhir tahun). Dalam melakukan pengambilan data, menggunakan sumber data sekunder yang merupakan data yang sudah di publikasikan melalui website bank indonesi. Data tersebut berupa laporan keuangan triwulan yang didalamnya terdapat laporang keuangan (financial statement) serta informasi tambahan lainnya atas perusahaan. 
2. Penelitian Lapangan (field research)

Penelitian ini dilakukan dengan mengadakan pengamatan langsung dan wawancara dengan pihakpihak yang terkait dengan PT. BPR Millenia Manado khususnya divisi kredit dan divisi akuntansi.

\section{Jenis Data}

1. Data kualitatif, yaitu data yang terdiri dari kumpulan data non angka yang sifatnya deskriptif yang terdiri dari berikut ini.

a. Gambaran umum perusahaan, struktur organisasi, dan sebagainya.

b. Buku pedoman perusahaan yang berisi pelaksanaan perlakuan akuntansi dan pelaksanaan proses pemberian kredit pada tepat penilitian.

c. Peraturan-peraturan yang dikeluarkan oleh Bank Indonesia yang ditetapkan oleh BPR Millenia.

2. Data kuantitatif, data berupa angka-angka yang diambil adalah Laporan Keuangan dan Catatan atas Laporan Keuangan PT BPR Millenia.

\section{Sumber Data}

1. Data Primer

Data yang diperoleh langsung dari perusahaan terkait melalui wawancara dengan petugas yang bertugas pada divisi kredit khususnya yang menangani masalah kredit.

2. Data Sekunder

Data yang diperoleh dari sumber di luar bank, yaitu Bank Indonesia dalam bentuk literatur-literatur perbankan dan IAI yang berhubungan dengan penilitian ini. Situs resmi Bank Indonesia yaitu www.bi.go.id

\section{Metode Analisis}

Metode analisis yang digunakan dalam penelitian ini adalah analisis deskriptif dan komparatif yaitu dengan menganalisis dan membandingkan antara penerapan perlakuan akuntansi penurunan nilai piutang (Impairment Piutang) serta penyajiannya dalam laporan keuangan sesuai dengan SAKETAP bab 22 dan PSAK No 50 dan PSAK No 55.

\section{Definisi Operasional}

SAK ETAP, Standar Akuntansi Keuangan Entitas Tanpa Akuntabilitas Publik merupakan standar akuntansi keuangan yang diperuntukkan bagi entitas tanpa akuntabilitas publik.

PSAK 50, instrumen keuangan penyajian. Pernyataan ini membantu perusahaan menklasifikasikan instrument keuangan dalam aset keuangan, liabilitas keuangan, instrumen ekuitas, termasuk juga klasifikasi yang terkait dengan bunga, dividen, kerugian dan keuntungan dan keadaan dimana aset keuangan dan liabilitas keuangan saling hapus.

PSAK 55, instrumen keuangan pengakuan dan pengukuran, memberikan panduan kepada pengakuan dan pengukuran instrumen keuangan dan kontrak untuk membeli item non-keuangan. Tujuannya untuk mengatur prinsip-prinsip dasar pengakuan dan pengukuran aset keuangan, kewajiban, keuntungan dan kontrak pembelian atau penjualan item non-keuangan.

Impairment Piutang, estimasi ini juga berupa penyisihan kerugian penurunan nilai. Perhitungan penyisihan kerugian penurunan nilai berdasarkan nilai tercatat (biaya perolehan amortisasi). Penyisihan penghapusan aktiva produktif adalah cadangan yang harus dibentuk sebesar presentase tertentu dari baki debet berdasarkan penggolongan kualitas aktiva produktif. Penurunan nilai adalah suatu kondisi dimana nilai tercatat aset melebihi nilai yang dapat diperoleh kembali.

\section{Hasil Penelitian}

\section{HASIL PENELITIAN DAN PEMBAHASAN}

PT Bank Perkreditan Rakyat Millenia membentuk penyisihan penghapusan aktiva produktif mengambil acuan pada Peraturan Bank Indonesia Nomor 13 / 26/PBI/2011. Dimana aktiva produktif adalah penyediaan dana BPR dalam Rupiah untuk memperoleh penghasilan, dalam bentuk Kredit, Sertifikat Bank Indonesia dan Penempatan Dana Antar Bank. Penyisihan Penghapusan Aktiva Produktif adalah cadangan yang harus dibentuk sebesar presentase tertentu dari baki debet berdasarkan penggolongan kualitas Aktiva Produktif. Penyisihan kerugian terbagi dua yaitu untuk kredit yang diberikan dan untuk kas, kas dalam valuta asing, surat berharga, dan penempatan pada 
bank lain. BPR menetapkan kualitas aktiva produktif yang sama terhadap beberapa rekening aktiva produktif yang digunakan untuk membiayai 1 (satu) debitur pada BPR yang sama.

Dalam hal terdapat perbedaan kualitas aktiva produktif terhadap beberapa rekening aktiva produktif untuk 1 (satu) debitur pada BPR yang sama, BPR wajib menetapkan kualitas masingmasing aktiva produktif mengikuti kualitas aktiva produktif yang paling rendah. BPR menentukan penyisihan kerugian penurunan nilai kredit secara kolektif dengan mengacu pada pembentukan penyisihan umum dan penyisihan khusus sesuai dengan ketentuan PBI mengenai penilaian kualitas aktiva. Penyisihan kolektif untuk kredit yang dikelompokkan sebagai kurang lancar, diragukan, dan macet, dihitung setelah dikurangi dengan nilai agunan yang diperkenankan sesuai dengan PBI.

PPAP umum ditetapkan paling kurang sebesar $0,5 \%$ dari aktiva produktif yang memiliki kualitas lancar.

PPAP khusus ditetapkan paling kurang sebesar :

1. $10 \%$ dari aktiva produktif yang memiliki kualitas lancar setelah dikurangi dengan nilai agunan;

2. 50\% dari aktiva produktif yang memiliki kualitas lancar setelah dikurangi dengan nilai agunan; dan

3. $100 \%$ dari aktiva produktif yang memiliki kualitas lancar setelah dikurangi dengan nilai agunan.

Sebelum tahun 2014 BPR tidak melakukan amortisasi pada biaya provisi, namun langsung diakui sebagai pendapatan. Pada tahun 2014 entitas mulai menerapkan amortisasi tiap bulan untuk kredit diatas Rp.5.000.000,- dengan metode suku bunga efektif.

Berikut jurnal pada saat pemberian kredit.

Kas

XXX

Kredit yang diberikan - Provisi Kredit XXX

(Kredit yang diberikan - Provisi Kredit penyajiannya sebagai aset pada laporan posisi keuangan).

Pada saat amortisasi tiap bulan.

Kredit yang diberikan - Provisi Kredit

XXX Pendapatan Provisi

$\operatorname{XXX}$

(Pendapatan provisi penyajiannya ada laporan laba rugi)

Pada saat debitur dianggap sudah tidak mampu atau mustahil untuk memenuhi kewajibannya maka entitas harus melakukan hapus buku dan hapus tagih. Penghapusan buku tidak akan dilakukan selama masih ada jaminan, dan untuk hapus tagih sangat jarang dilakukan namun terpaksa dilakukan bila pihak debitur telah meninggal dunia atau tidak diketahui keberadaannya.

Jurnal pada saat hapus buku

PPAP - kyd

$\mathrm{XXX}$

Kredit yang diberikan

XXX

*) Penyajiannya pada neraca

Namun pihak debitur membayar kredit yang telah dihapus buku, maka akan dijurnal pada catatan khusus atas laporan keuangan

Kas

$\mathrm{XXX}$

Pendapatan tagihan hapus buku

$\mathrm{XXX}$

\section{Pembahasan}

\section{Penurunan Nilai SAK ETAP}

Penyisihan Kerugian Kredit dibentuk untuk menutup kemungkinan kerugian yang timbul sehubungan dengan penanaman dana ke dalam kredit. Penghapusbukuan kredit (hapus tagih) adalah tindakan BPR menghapus kewajiban buku kredit macet dari neraca sebesar kewajiban debitur tanpa menghapus hak tangih BPR kepada debitur. Penghapusan hak tagih kredit (hapus tagih) adalah tindakan BPR menghapus kewajiban debitur yang tidak dapat diselesaikan.

Penurunan nilai penjaman yang diberikan dan piutang dibentuk sebesar estiasi kerugian yang tidak dapat ditagih (SAK ETAP paragraf 22.2). Penurunan nilai ditentukan dengan memperhatikan antara lain pengalaman, prospek industri, debitur dan agunan yang dikuasai. Pemulihan nilai pinjaman yang diberikan dan piutang mengacu ke paragraf 22.15, 22.17 dan 22.18 (SAK ETAP paragraf 22.23).

Persentase penyisihan kerugian penurunan nilai aset diatas diterapkan terhadap saldo aktiva produktif setelah dikurangi dengan nilai agunan sesuai dengan PBI, kecuali untuk aktiva produktif yang diklasifikasikan lancar dan tidak dijamin atau yang dijamin dengan agunan non-tunai, dimana persentase penyisihan kerugian penurunan nilai aset diterapkan terhadap saldo aktiva produktif yang bersangkutan. 


\section{Ilustrasi jurnal sebagai berikut.}

1. Pada saat pembentukan penyisihan kerugian kredit. Beban penyisihan kerugian kredit

Penyisihan kerugian kredit

XXX

XXX

XXX

XXX

Kredit yang diberikan

3. Pencatatan extracomptable atau rekening memorial. Memorial kredit yang dihapus buku

Rekening lawan-memorial kr yang dihapus buku

Pada saat penghapusbukuan kredit

Penyisihan kerugian kredit

$\mathrm{xxx}$

4. Pada saat menerima setoran dari debitur atas kredit yang telah dihapus buku.

Kas/Rekening

$\mathrm{XXX}$

Pendapatan operasional lainnya

$\mathrm{XXX}$

5. Pengurangan catatan extracomptable atau rekening memorial sebagai berikut:

Rekening lawan-memorial $\mathrm{kr}$ dihapus buku $\quad \mathrm{xxx}$

Memorial kredit yang dihapus buku $\quad$ XXx

\section{Penurunan Nilai PSAK 55}

Sesuai dengan PSAK 55 Entitas pada setiap akhir periode pelaporan, entitas mengevaluasi apakah terdapat bukti efektif bahwa aset keuangan atau kelompok aset keuangan mengalami penurunan nilai. Penurunan nilai yaitu suatu kondisi dimana terdapat bukti obyektif terjadinya peristiwa yang merugikan akibat satu atau lebih peristiwa yang terjadi setelah pengukuran awal aset tersebut dan peristiwa merugikan yang berdampak pada estimasi arus kas masa datang aset keuangan yang dapat diestimasi secara handal. Pengukuran tersebut dilakukan secara individual maupun kolektif.

Penurunan nilai adalah suatu kondisi dimana nilai tercatat aset melebihi nilai yang dapat diperoleh kembali. Sedangkan Cadangan Kerugian Penurunan Nilai (Impairment Loss) adalah jumlah yang diturunkan dari nilai tercatat hingga menjadi sebesar nilai yang dapat diperoleh kembali dari asset.

Menurut PAPI, Cadangan Kerugian Penurunan Nilai adalah cadangan yang wajib dibentuk bank jika terdapat bukti obyektif mengenai penurunan nilai atas aset keuangan atau kelompok aset keuangan sebagai akibat dari satu atau lebih peristiwa yang terjadi setelah pengakuan awal aset tersebut (peristiwa yang merugikan) dan berdampak pada estimasi arus kas mas depan. Jumlah cadangan kerugian diukur sebagai selisih antara nilai tercatat aset keuangan dengan nilai kini estimasi arus kas masa depan yang didiskonto menggunakan suku bunga efektif awal dari aset keuangan.

Aset keuangan atau kelompok aset keuangan diturunkan nilainya dan kerugian penurunan nilai telah terjadi, jika dan hanya jika, terdapat bukti objektif mengenai penurunan nilai sebagai akibat dari satu atau lebih peristiwa yang terjadi setelah pengakuan awal aset tersebut (peristiwa merugikan), dan peristiwa yang merugikan tersebut berdampak pada estimasi arus kas masa depan dari aset keuangan atau kelompok aset keuangan yang dapat diestimasi secara andal.

Bank membentuk CKPN berdasarkan data kerugian kredit yang telah terjadi (incured loss) yang diambil dari data tiga tahun sebelumnya, bank pada setiap tanggal neraca, bank mengevaluasi apakah terdapat bukti terdapat bukti objektif bahwa aset keuangan yang tidak dicatat pada nilai wajar melalui laporan laba rugi telah mengalami penurunan nilai. Aset keuangan mengalami nilai jika bukti objektif menunjukkan bahwa peristiwa yang merugikan telah terjadi setelah pengakuan awal aset keuangan dan peristiwa tersebut berdampak pada arus kas masa datang atas aset keuangan yang dapat diestimasi secara handal.

Bank pertama kali menentukan apakah terdapat bukti obyektif penurunan nilai secara individual atas aset keuangan yang signifikan secara individual atau kolektif untuk aset keuangan yang tidak signifikan secara individual. Jika bank menentukan tidak terdapat bukti objektif mengenai penurunan nilai atas aset keuangan yang dinilai secara individual, terlepas aset tersebut signifikan atau tidak, maka bank memasukkan aset tersebut kedalam kelompok aset keuangan yang memiliki karakteristik risiko kredit yang serupa dan menilai penurunan nilai kelompok tersebut secara kolektif. Aset keuangan yang penurunan nilainya dilakukan secara individual, dan untuk itu kerugian 
penurunan nilai telah diakui atau tetap diakui tidak termasuk dalam penilaian penurunan nilai secara kolektif.

\section{Ilustrasi Jurnal}

1. Pada saat terdapat bukti obyektif penurunan nilai, membentuk cadangan kerugian penurunan nilai.

Db. Kerugian penurunan nilai kredit

Kr. Cadangan kerugian penurunan nilai kredit

2. Membatalkan pendapatan bunga yang telah diakui dan belum diterima pembayarannya dengan melakukan jurnal balik apabila penurunan nilai terjadi pada periode berjalan.

Db. Pendapatan bunga kredit

Db./Kr. Kredit - amortised cost

Kr. Pendapatan bunga kredit yang akan diterima

3. Mengoreksi saldo laba, jika bukti obyektif penurunan nilai kredit yang diperoleh setelah tanggal neraca tetapi sebelum tanggal penyelesaian laporan keuangan menunjukkan terjadinya penurunan nilai sebelum atau pada tanggal neraca.

Db. Saldo laba

Db./Kr. Kredit - amortised cost

Kr. Pendapatan bunga kredit yang akan diterima,

4. Jika penurunan nilai terjadi pada periode berjalan dan bank masih memiliki saldo tagihan bunga yang pendapatannya telah diakui pada periode sebelumnya, maka saldo tagihan bunga tersebut dijurnal balik dan bank mengakui kerugian penurunan nilai pada periode berjalan.

Db. Kerugian penurunan nilai

Kr. Pendapatan bunga kredit yang akan diterima

Kr. Cadangan kerugian penurunan nilai kredit

5. Pada saat penghapusbukuan kredit

Db. Cadangan kerugian penurunan nilai kredit

Kr. Kredit

Tabel Perbandingan Penurunan Nilai SAK ETAP dan PSAK 50 dan 55

\begin{tabular}{|c|c|c|}
\hline Uraian & SAK ETAP & PSAK 50 dan 55 \\
\hline Pengakuan Awal & Saldo Pinjaman - PKPN & $\begin{array}{l}\text { Nilai wajar ditambah biaya transaksi yang } \\
\text { diatribusikan secara langsung ditambah biaya } \\
\text { tambahan untuk memperoleh aset keuangan } \\
\text { tersebut, dan selanjutnya diukur pada biaya } \\
\text { perolehan diamortisasi menggunakan suku bunga } \\
\text { efektif dikurangi PKPN }\end{array}$ \\
\hline Penurunan Nilai & $\begin{array}{l}\text { Kerugian penurunan nilai terjadi ketika } \\
\text { nilai tercatat aset melebihi jumlah yang } \\
\text { dapat diperoleh kembali }\end{array}$ & $\begin{array}{l}\text { Penurunan nilai adalah kondisi terdapat bukti } \\
\text { obyektif terjadinya peristiwa yang merugikan }\end{array}$ \\
\hline $\begin{array}{l}\text { Pembentukan } \\
\text { Penurunan Nilai }\end{array}$ & $\begin{array}{l}\text { Penurunan nilai pinjaman yang diberikan } \\
\text { dan piutang dibentuk sebesar estimasi } \\
\text { kerugian yang tidak dapat ditagih. } \\
\text { (PPAP) }\end{array}$ & $\begin{array}{l}\text { Penurunan yang dibentuk apabila nilai tercatat } \\
\text { kredit setelah penurunan nilai kurang dari nilai } \\
\text { tercatat awal (CKPN). Apabila terdapat selisih } \\
\text { dalam nilai tercatat kredit maka akan muncul } \\
\text { akun CKPN. }\end{array}$ \\
\hline $\begin{array}{l}\text { Pembentukan } \\
\text { Penurunan Nilai }\end{array}$ & Historical Cost & $\begin{array}{l}\text { Terdapat dua teknik evaluasi penurunan nilai } \\
\text { yaitu individual dan kolektif. } \\
\text { Proses estimasi terhadap jumlah kerugian } \\
\text { penurunan nilai dapat menghasilkan satu nilai } \\
\text { kerugian atau kisaran (range) nilai kerugian yang } \\
\text { mungkin terjadi (PSAK 55: PA 102). }\end{array}$ \\
\hline $\begin{array}{l}\text { Penyisihan Kerugian } \\
\text { Penurunan Nilai }\end{array}$ & Expectation Loss & Incured Loss \\
\hline $\begin{array}{l}\text { Peristiwa-Peristiwa } \\
\text { Merugikan }\end{array}$ & $\begin{array}{l}\text { 1. pengalaman, } \\
\text { 2. prospek industri, } \\
\text { 3. prospek usaha, }\end{array}$ & $\begin{array}{l}\text { 1. Kesulitan keuangan signifikan yang dialami } \\
\text { pihak peminjam } \\
\text { 2. Pelanggaran Kontrak }\end{array}$ \\
\hline
\end{tabular}




\begin{tabular}{|c|c|c|}
\hline & $\begin{array}{l}\text { 4. kondisi keuangan dengan penekanan } \\
\text { pada arus kas, } \\
\text { 5. kemampuan membayar debitor, } \\
\text { 6. agunan yang dikuasai. }\end{array}$ & $\begin{array}{l}\text { 3. Terdapat kemungkinan pailit dari pihak } \\
\text { peminjam } \\
\text { 4. Hilangnya pasar aktif dari aset keuangan } \\
\text { akibat kesulitan keuangan } \\
\text { 5. Memburuknya status pembayaran pihak } \\
\text { peminjam } \\
\text { 6. Kondisi ekonomi nasional. }\end{array}$ \\
\hline $\begin{array}{l}\text { Pada saat } \\
\text { pembentukan } \\
\text { penyisihan kerugian } \\
\text { kredit }\end{array}$ & $\begin{array}{l}\text { Db. Beban Penyisihan Kerugian Kredit } \\
\text { Kr. Penyisihan Kerugian Kredit }\end{array}$ & $\begin{array}{l}\text { Db. Kerugian Penurunan Nilai Kredit } \\
\text { Kr. Cadangan Kerugian Penurunan Nilai Kredit }\end{array}$ \\
\hline $\begin{array}{l}\text { Pada saat } \\
\text { penghapusbukuan } \\
\text { kredit }\end{array}$ & $\begin{array}{l}\text { Db. Penyisihan Kerugian Kredit } \\
\text { Kr. Kredit yang diberikan }\end{array}$ & $\begin{array}{l}\text { Db. Cadangan Kerugian Penurunan Nilai Kredit } \\
\text { Kr. Kredit yang diberikan }\end{array}$ \\
\hline
\end{tabular}

Sumber : Data Olahan (2015)

\section{Kesimpulan}

\section{PENUTUP}

Berdasarkan hasil penelitian dan analisis yang telah diuraikan pada bagian pembahasan, maka dapat dikemukakan kesimpulan sebagai berikut.

PT. Bank Perkreditan Rakyat Millenia dalam pengakuan dan pengukuran penyisihan kerugian penurunan nilai (impairment loss), pihak perbankan telah sesuai dengan Peraturan Bank Indonesia Nomor 13/26/PBI/2011 yang mengacu pada SAK ETAP. SAK ETAP sendiri berbeda atau tidak sepenuhnya mengikuti PSAK 50 dan PSAK 55. Dalam hal penyajian dan pengakuan telah sesuai seperti pada pinjaman yang diberikan pengakuan awal pinjaman yang diberikan dan piutang diukur dalam nilai wajar ditambah dengan biaya transaksi yang dapat di atribusikan secara langsung dengan perolehan aset keuangan, Pengukuran selanjutnya diukur pada biaya perolehan diamortisasi dengan menggunakan metode suku bunga efektif dikurangi penurunan nilai. Kemudian untuk penyajian keuntungan dan kerugian telah sesuai dengan PSAK 55 paragraf 56 dimana aset keuangan yang dicatat pada biaya perolehan diamortisasi, keuntungan dan kerugian diakui dalam laba rugi ketika aset keuagan tersebut dihentikan pengakuannya atau mengalami penurunan nilai, dan melalui proses amortisasi. Namun dalam hal pengukuran penurunan atau penyisihan kerugian penurunan nilai tidak sesuai karena, PSAK 55 tidak mengizinkan pengakuan kerugian penurunan nilai melalui pembentukan cadangan untuk kerugian di masa depan pada saat pinjaman diberikan. PSAK 55 paragraf 43 mensyaratkan aset keuangan pertama kali dinilai berdasarkan nilai wajar. Untuk aset berbentuk pinjaman, nilai wajar adalah total kas yang dipinjamkan setelah disesuiakan dengan fee dan biaya lain. Selanjutnya PSAK 55 paragraf 58 mensyaratkan bahwa kerugian penurunan nilai hanya diakui jika terdapat bukti objektif penurunan nilai yang disebabkan peristiwa masa lalu yang terjadi setelah pengakuan awal. Sejalan dengan hal tersebut, pengurangan jumlah tercatat suatu aset berbentuk pinjaman pada saat pengakuan awal melalui pengakuan seketika kerugian penurunan nilai adalah tidak konsisten dengan PSAK 55 paragraf 43 dan 58.

Perbedaan penggunaan SAK ETAP dan PSAK 50 dan 55 dalam penyajian, pengakuan, dan pengukuran dengan penggunaan PSAK 50 dan PSAK 55. Pada perhitungan penurunan nilai (impairment) piutang, dalam hal pengukuran penyisihan SAK ETAP tidak menetapkan cadangan kerugian penurunan nilai yang berdasarkan pada penurunan nilai namun, ini memungkinkan perbankan mengatur besarnya pencadangannya untuk tujuan tertentu. Pihak perbankan tidak menentukan penyisihan penurunan nilai berdasarkan data kerugian kredit yang telah terjadi (incured loss) yang diambil dari data tiga tahun sebelumnya. Namun penentuan pencadangannya yaitu penyisihan penghapusan aktiva produktif menggunakan ekspektasi kerugian kredit (expectation loss) yang ditentukan oleh perbankan tersebut. Dengan kata lain bahwa penerapan regulasi ini bank dapat dengan mudah mempercantik laporan keuangannya karena tidak memakai sumber data yang diambil dari data-data transaksi minimal tiga tahun atau maksimal lima tahun sebelumnya. Perbankan memoles laporan keuangannya dengan memperbesar PPAP-nya sehingga akan mempengaruhi kinerjanya. Penyisihan kerugian penurunan nilai berguna untuk menilai kinerja perbankan sendiri khususnya untuk nonperforming. 


\section{Saran}

Berdasarkan kesimpulan yang telah dibuat, maka penulis mengemukakan saran sebagai berikut. Perlakuan Akuntansi PT. Bank Perkreditan Rakyat Millenia atas Penurunan Nilai telah sesuai berdasarkan SAK-ETAP, maka penulis menyarankan agar PT. Bank Perkreditan Rakyat Millenia terus mempelajari, mendalami tentang SAK ETAP khususnya dalam hal penurunan nilai (impairment) agar terus mematuhi Peraturan Bank Indonesia, dan membentuk Penyisihan Penghapusan Aktiva Produktif benar-benar berdasarkan data, dan tanpa adanya permainan mengingat penggunaan SAK ETAP yang lebih mudah (simple) dibandingkan dengan PSAK 50 dan 55.

\section{DAFTAR PUSTAKA}

Belkaoui Ahmad. 2006. Accounting Theory. Buku 1 Edisi 5. Salemba Empat : Jakarta Selatan.

Bank Perkreditan Rakyat Sulut Indonesia. http://www.bankmillenia.com. Tanggal Akses 16 September 2015.

Demiroglu \& James. 2010. The use of Bank Lines of Credit in Corporate Liquidity Management : A Review of Empirical Evidence. Koc University. Florida. Tanggal Akses 24 November 2015.

Emanuela. 2012. Analisis Penerapan PSAK 50 dan 55 (Revisi 2006) atas Impairment Piutang pada Perusahaan Multifinance. Skripsi. Universitas Indonesia. Jakarta.

Fitria dan Sari. 2012. Analisis Kebijkan Pemberian Kredit dan Pengaruh Non Performing Loan terhadap Loan to Deposit Ratio pada PT. Bank Rakyat Indonesia (Persero), Tbk. Cabang Rantau, Aceh Tamiang (Periode 2007-2011). No.1 Vol.1 Hal 88-101. Jurnal Ekonomi dan Keuangan. Tanggal Akses 2 Januari 2016.

Ikatan Akuntan Indonesia. 2015. Standar Akuntansi Keuangan. Cetakan kedua. Dewan Standar Akuntansi Keuangan Ikatan Akuntan Indonesia, Jakarta.

Inggrid, 2012. Analisis Pengakuan, Pengukuran, Penyajian, Pengungkapan Atas Pendapatan Bunga Kredit Pada PT Bank Sinar Mas Tbk. Skripsi, Universitas Sam Ratulangi, Manado.

Ismail, 2014. Akuntansi Bank. PT. Kencana Prenadamedia Group : Jakarta.

Jayanti Andy. 2012. Perlakuan Akuntansi Kredit Bermasalah (Non Performing Loan) Kesesuaiannya Sebelum dan Sesudah Pernyataan Standar Akuntansi Keuangan No.31 Efektif Dicabut Pada PT. Bank Negara Indonesia (Persero) Tbk. Skripsi. Universitas Hasanuddin. Makassar.

Kasmir. 2012. Bank dan Lembaga Keuangan lainnya. PT. Raja Grafindo Persada : Jakarta.

Kuncoro, Mudrajad, Suhardjono. 2002. Manajemen Perbankan Teori dan Aplikasi. Yogjakarta : BPFE UGM.

Martani Dwi, 2014. PSAK 50 Instrumen Keuangan Penyajian, https://staff.blog.ui.ac.id/martani/PSAK-50-InstrumenKeuangan-Penyajian15122014.pptx. Tanggal Akses 8 Agustus 2015.

Martani Dwi, 2014. PSAK 55 Instrumen Keuangan Pengakuan dan Pengukuran, https://staff.blog.ui.ac.id/martani/PSAK-55-InstrumenKeuangan-Pengakuan-

15122014.pptx. Tanggal Akses 8 Agustus 2015.

Martani Dwi, 2011. Standar Akuntansi Keuangan Entitas Tanpa Akuntabilitas Publik, https://staff.blog.ui.ac.id/martani/SAK-ETAP-155112011.pptx. Tanggal Akses 2 November 2015.

Soemarso SR. 2014. Akuntansi Suatu Pengantar. Buku 1 Edisi 5. Salemba : Jakarta.

Sumendap Priscilia. 2015. Evaluasi Penerapan SAK ETAP pada PT.BPR Cipta Cemerlang Indonesia. No.04 Vol.15. Universitas Sam Ratulangi. Indonesia. Tanggal Akses 28 November 2015 
Sugiyono. 2011. Metode Penelitian Bisnis (Pendekatan Kuantitatif, Kualitatif, dan R\&D). Alfabeta. Bandung

Taufiq, 2013. SAK ETAP unsera, www.slideshar.net/ceceptaufiqkurochman/sak-etapunsera. Tanggal Akses 19 Oktober. 